\title{
Proteomic Changes in Pseudomonas aeruginosa Biofilm Cells after Adaptive Resistance Development
}

\author{
Idalina Machado ${ }^{1,3^{*}}$, Laurent Coquet ${ }^{2}$, Maria Olívia Pereira ${ }^{1}$ and Thierry Jouenne ${ }^{2}$ \\ ${ }^{1}$ IBB - Institute for Biotechnology and Bioengineering, Centre of Biological Engineering, University of Minho, Campus de Gualtar, 4710-057 Braga, Portugal \\ ${ }^{2}$ CNRS, UMR 6270, Laboratory "Polymères, Biopolymères, Surfaces", PISSARO proteomic platform, Rouen University, France \\ ${ }^{3}$ Department of Chemical Engineering, Faculty of Engineering, University of Porto, Rua Dr. Roberto Frias, s/n, $4200-465$ Porto, Portugal
}

\begin{abstract}
This work investigates the outer membrane (OM) proteomic alteration of Pseudomonas aeruginosa biofilm cells after adaptation to benzalkonium chloride (BC) and ciprofloxacin (CIP). Biofilms were formed in 6-well plates for 24 $\mathrm{h}$ being after submitted to $324 \mathrm{mg} / \mathrm{L} \mathrm{BC}$ and $6.0 \mathrm{mg} / \mathrm{L} \mathrm{CIP}$, during 12 days. Cells were harvested, the OM proteins extracted and patterns compared. $P$. aeruginosa adaptation altered the total amount of six proteins, about $10 \%$ of the discriminated proteins on two-dimensional gels. Exposure to both antimicrobials generated a common downregulation of three proteins, GroEL, the major capsid protein and the putative tail sheath protein. The type 4 fimbrial biogenesis outer membrane protein PilQ precursor was over-expressed only in biofilm cells submitted to BC, while the probable bacteriophage protein and the hypothetical protein PA0537 were overexpressed in CIP exposed biofilm cells. The alterations in OMPs expression might be involved in the biofilm bacteria high resistance to antimicrobial agents.
\end{abstract}

Keywords: Pseudomonas aeruginosa; Biofilms; Proteome; Chemical adaptation

\section{Introduction}

The Gram-negative bacterium Pseudomonas aeruginosa is a major cause of infection in hospitalized, immunocompromised, and cystic fibrosis patients and is considered an intrinsic resistant organism [1]. $P$. aeruginosa resistance is often associated with its high ability to attach to a surface and to form biofilms [2]. In this type of communities cells are embed within a matrix of exopolymeric substances [3], in particular polysaccharides, proteins, and nucleic acids [4]. Though increased biofilm tolerance to antimicrobials is not yet fully understood, several mechanisms have been recognized as playing major roles: (i) slow microbial growth rate $[5,6]$; (ii) the emergence of persister cells; (iii) the diffusion barrier promoted by the biofilm matrix that prevents antimicrobials to reach their targets, and (iv) intercellular signals that alter the biofilm physiology, causing bacteria to produce molecular pumps that expel antibiotics from the cells and allow the community to tolerate the presence of the drug [7]. In order to effectively kill bacteria embedded in biofilms, high doses of antibiotics applied during long periods of time should be used, however, due to toxicity issues this is not feasible [8]. Anti-biofilm agents, like biocides, usually kill only external cell layers of biofilms, exposing the inner-entrapped biofilm cells to gradually reduced concentrations of the antimicrobial products and thus the enclosed protected bacterial cells persist and instigate biofilm regrowth. This exposure to supra-minimum inhibitory concentrations (MIC) frequently induce the development of adaptive resistance to antimicrobial agents [9]. It is now known that this type of resistance, caused by exposure to supra-MIC levels of antibiotics, can induce alterations in gene and / or protein expression [10]. This type of adaptive resistance to antimicrobials is a way of antimicrobial stress response and has been widely reported in planktonic growth and studied through phenotypic characterization and proteomic analyses [11-14]. Concerning biofilm adaptation, the increased resistance and the mechanisms at the membrane level of biofilm-entrapped cells to antimicrobial exposure have been scarcely studied. The proteins specifically recruited to cause biofilm resistance when compared with the free floating cells have rapidly emerged at the beginning of the 2000s [15-20]. Multivariate analyses demonstrated that the biofilm growth mode leads to a specific bacterial proteome in sessile bacteria as compared to their planktonic counterparts [19,21-25]. However, as recently pointed out by Seneviratne [26], data regarding biofilm antimicrobial-induced proteomic changes are sparse. The present study aimed at characterizing the proteomic changes, induced at the outer membrane level of $P$. aeruginosa cells that persist in biofilms exposed to benzalkonium chloride (BC) and ciprofloxacin (CIP). With this, it is intended to identify possible pathways associated with biofilm adaptation to antimicrobial agents (biocides and antibiotics) bringing know-how regarding the possible cross-resistance mechanisms observed in biofilms.

\section{Experimental Procedures}

\section{Strain and culture conditions}

Pseudomonas aeruginosa (ATCC 10145 strain) was stored at -80 $\pm 2{ }^{\circ} \mathrm{C}$ in $10 \%$ glycerol stocks. Prior to each experiment, bacterial cells were grown on Tryptic Soy Agar (TSA, Merck) plates for $24 \mathrm{~h}$, at $37^{\circ} \mathrm{C}$.

\section{Antibacterial agents}

Benzalkonium chloride (BC), a quaternary ammonium compound, widely used in clinical disinfectant formulations, was purchased from Calbiochem (Merck Biosciences, UK). Ciprofloxacin (CIP) is a broad-

*Corresponding author: Idalina Machado, Department of Chemical Engineering Faculty of Engineering, University of Porto, Rua Dr. Roberto Frias, s/n, 4200-465 Porto, Portugal, Tel: 0035122508 3658; E-mail: idalinam@fe.up.pt

Received January 07, 2016; Accepted March 02, 2016; Published March 09 2016

Citation: Machado I, Coquet L, Pereira MO, Jouenne T (2016) Proteomic Changes in Pseudomonas aeruginosa Biofilm Cells after Adaptive Resistance Development. J Proteomics Bioinform 9: 058-062. doi:10.4172/jpb.1000390

Copyright: (c) 2016 Machado I, et al. This is an open-access article distributed under the terms of the Creative Commons Attribution License, which permits unrestricted use, distribution, and reproduction in any medium, provided the original author and source are credited. 
spectrum fluoroquinolone purchased from Fluka, used clinically to treat chronic $P$. aeruginosa infections.

\section{Biofilm development}

The methodology used for biofilms formation was based on the microtiter plate test developed by Stepanovic et al. [27]. Cell suspensions of $P$. aeruginosa, were diluted in TSB to obtain a final concentration around $10^{7} \mathrm{cfu} / \mathrm{ml}$. Two millilitres per well of the bacterial suspension were then transferred into sterile 6-well tissue culture plates (Orange Scientific, Braine-l'Alleud, Belgium). Plates were incubated aerobically on a horizontal shaker $(120 \mathrm{rpm})$, at $37^{\circ} \mathrm{C}$, during $24 \mathrm{~h}$ to form biofilms.

\section{Biofilm adaptation}

After biofilm formation, the content of each well was removed. After washing with $3 \mathrm{ml}$ of ultra-pure (UP) sterilized water, $3 \mathrm{ml}$ of TSB supplemented with $324 \mathrm{mg} / \mathrm{L}$ BC or $6.0 \mathrm{mg} / \mathrm{L}$ CIP were added. Every 24 $\mathrm{h}$, the content of each well was removed and $2 \mathrm{ml}$ of fresh medium with antimicrobials were added into each well. This procedure was repeated for 12 subsequent days. The content of each well was then removed and biofilms were washed twice with $3 \mathrm{~mL}$ of UP water. Control biofilms, i.e., non-adapted biofilms, were done for the same period of time using the same protocol but without antimicrobials. Attached bacteria were harvested by scraping with a sterile rubber scraper until the wells were visually clear, and bacteria were then resuspended in UP water. The resulting suspension was vigorously vortexed and stored at $-80^{\circ} \mathrm{C}$ until needed.

\section{Proteomics}

Preparation and analysis of outer membrane protein (OMP) extracts: Bacterial cultures were centrifuged for $15 \mathrm{~min}$ at $3500 \times \mathrm{g}$ and the pellets were suspended in $1 \mathrm{ml}$ of (3-[(3-Cholamidopropyl) dimethylammonio]-1 propanesulfonate) (CHAPS). Cells were then disrupted by sonication (Ultrasonic Processor, Cole-Parmer, USA) using $10 \mathrm{~W}$ powers for 6 pulses of $10 \mathrm{~s}$ (separated by 2 -s breaks) on ice. Unbroken cells and cell debris were removed from the resulting suspension by centrifugation at $7000 \times \mathrm{g}$ for $10 \mathrm{~min}$ at $4^{\circ} \mathrm{C}$. The supernatant was then centrifuged at $100,000 \times \mathrm{g}$ for $1 \mathrm{~h}$ at $4^{\circ} \mathrm{C}$, the formed pellet representing the total membrane fraction. The separation of the bacterial membranes was adapted from the protocol described by Winder et al. [28]. Membrane proteins were incubated in $25 \mathrm{ml}$ of $2 \%(\mathrm{w} / \mathrm{v})$ sodium lauryl sarcosinate solution at room temperature for $1 \mathrm{~h}$, followed by centrifugation at $100,000 \times \mathrm{g}$ for $1 \mathrm{~h}$ at $4^{\circ} \mathrm{C}$. The resulting pellet, i.e., the outer membrane fraction, was resuspended in $1 \mathrm{ml}$ of UP water. The protein amount was measured using the Bio-Rad protein assay (Bio-Rad, Hercules, CA).

Two-dimensional gel electrophoresis: OMPs patterns were analyzed by two-dimensional gel electrophoresis (2-DE). Two hundred micrograms of proteins were added to isoelectric focusing (IEF) buffer (final volume, $300 \mu \mathrm{l}$ ) [29] with the following composition: $5 \mathrm{M}$ urea, $2 \mathrm{M}$ thiourea, $1 \%$ amidosulfobetaine-14 (ASB-14), 2\% w/v DTT and $2 \% \mathrm{v} / \mathrm{v}$ carrier ampholytes 4-7 NL. The first-dimension was carried out with Immobiline Dry Strips L ( $\mathrm{pH} \mathrm{4-7,} \mathrm{Amersham} \mathrm{Pharmacia}$ Biotech). The second dimension was obtained by a SDS-PAGE using a $12.5 \%(\mathrm{w} / \mathrm{v})$ polyacrylamide resolving gel (width $16 \mathrm{~cm}$, length $20 \mathrm{~cm}$, thickness $0.75 \mathrm{~mm}$ ). After migration, proteins were visualized by silver nitrate staining [30].

Gel analysis: Spot quantification was achieved by computing scanning densitometry (ProXPRESS 2D, PerkinElmer Sciex). Gels were analyzed using the Progenesis Samespot (Nonlinear Dynamics) software. For each experimental condition, three 2-DE gels were matched together to form a reference image. The two reference gels were then matched together so that the same spot in different gels had the same number. Protein spots from the two bacterial populations were considered to display significant quantitative differences if they fulfilled the following criteria: $\mathrm{p}$ values 0.05 (t-test); detection threshold, average volume $\geq 20(n=3)$; differential tolerance, fold change $\geq 2$ [23].

Protein identification: Spots excised from the polyacrylamide gel complied with the following criteria: volume varying with the incubation conditions and displaying a high (average) value with a low coefficient of variation. Gel plugs were dried using a SpeedVac centrifuge. Trypsin digestion was performed using an automatic digester (MultiPROBE II, PerkinElmer Sciex). After lyophilization, the peptide extracts were resuspended in $10 \mu \mathrm{L}$ of $0.2 \%$ formic acid / $5 \%$ acetonitrile.

Peptides were enriched and separated using a lab-on-a-chip technology (Agilent, Massy, France) and fragmented using an online XCT mass spectrometer (Agilent). The fragmentation data were interpreted using the Data Analysis program (version 3.4, Bruker Daltonic). For protein identification, MS / MS peak lists were extracted and compared to the NCBInr protein database restricted to $P$. aeruginosa (Version 4, 1,342,017 residues, 4243 sequences), using the MASCOT Daemon search engine. All searches were performed with no fixed modification and allowed for carbamidomethylation, oxidation and a maximum of one missed trypsin cleavage. MS / MS spectra were searched with a mass tolerance of $1.6 \mathrm{Da}$ for precursor ions and 0.8 $\mathrm{Da}$ for fragment ions, respectively. If a protein was characterized by 2 peptides with a fragmentation profile score higher than 25 the protein was validated. When one of the criteria was not met, peptides were systematically checked and / or interpreted manually to confirm or cancel the MASCOT suggestion.

Bioinformatic tools for subcellular location: The prediction of identified proteins location, and in particular for unknown proteins, within the bacterial cell, was realized from the genome annotation of $P$. aeruginosa (accessible at http://www.pseudomonas.com).

\section{Results and Discussion}

\section{Biofilm proteins extraction}

Biofilm proteomic investigations generally comprise the characterization of the alterations of the protein patterns between planktonic and sessile organisms, and during the different developmental biofilm stages $[23,31,32]$. In the present study, the alterations of the OM proteome of sessile $P$. aeruginosa cells after adaptation for 12 days to supra-MIC of two antimicrobials were characterized. It has been shown that permeability changes caused by antimicrobials exposure can lead to bacterial adaptive resistance to antimicrobial agents [33]. Particularly, biocides are known to induce alterations in bacterial OM, fatty acid changes as well as changes in active efflux [12]. Regarding adaptive resistance induced by fluoroquinolones like CIP, some studies $[12,34]$ showed that the main adaptive resistance mechanism is related with the dysregulation of genes encoding the MexAB efflux pump, and that more generally, the cell envelope plays a key role in this type of bacterial resistance [35-38]. Often performed on planktonic cultures [12], such studies have been rarely performed on biofilm organisms. High doses of antimicrobials were here used in order to ensure the selection of $P$. aeruginosa biofilm cells, which were able to survive upon a long exposure to these agents.

About 600 proteins were discriminated with $\mathrm{p}<0.05$ and fold $>2$ 
(Figure 1). Due to the small number of gels that could be analysed for each condition ( 3 gels), it was also considered the $\mathrm{q}$ value $(\mathrm{q} \leq 0.05)$ to guarantee that no false positives were mistakenly analysed. The protein expression of the biofilm-growing bacteria challenged by $\mathrm{BC}$ and CIP is listed in Table 1 and shown in Figure 2. The main difficulty during sample preparation was related with the reduced number of bacteria that developed adaptive resistance and survived within the stressed biofilm and, in consequence the reduced concentration of OMPs obtained in each extraction. Additionally, the difficulties felt during due to the presence of biofilm matrix within the suspension of bacterial cells may also lead to sample contamination. This difficulty became even higher when biofilms were developed under chemical stress since more extracellular polymeric substances were secreted by bacteria in order to defend the surviving cells from the aggression [2,5]. Consequently, an increase in sample contaminants was observed when

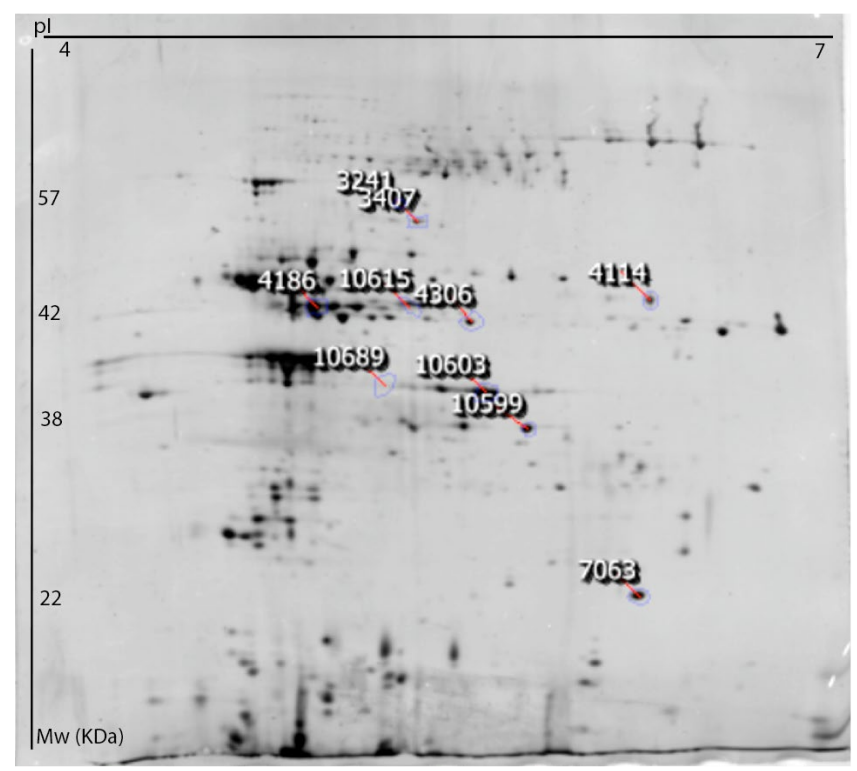

Figure 1: Silver-stained experimental two-dimensional gel electrophoresis map obtained with an outer membrane extract of Pseudomonas aeruginosa biofilm cells (protein loading $200 \mu \mathrm{g}$ ). biofilms were developed under stress compared with control biofilms. Ten modified spots were common to the two adapted populations. All these spots were down-regulated both in BC-adapted and CIP-adapted biofilm cells. The identification of the corresponding proteins is given in Table 1. The low percentage of modified OMPs may suggest that this specific bacterial adaptation induced small alterations at OMP level of the biofilm-adapted organisms. This observation may witness the over-expression of stress proteins by sessile cells even in the absence of antimicrobials, due to environmental conditions prevailing within the matrix [32].

\section{Down-regulated proteins}

Biofilm exposure to BC and CIP generated a down-regulation of four same proteins: GroEL, the predicted major capsid protein, the putative tail sheath protein, and a hypothetical protein PA0537 (Table 1).

GroEL was found in several spots $(3241,3407,4114)$, as well as putative tail sheath protein $(4186,4306)$, pointing out some translational modifications [37]. Posttranslational modifications of GroEL have already been observed both in the membrane, cytoplasmic and periplasmic compartments [14,39]. Indeed, though this protein is predominantly cytoplasmic, it has been found in all the cellular compartments $[1,40]$. It has been shown that this protein facilitates the folding process of membrane associated proteins [41], and participates in bacteria adhesion to tissues [42]. Though downregulated in sessile bacteria adapted to both antimicrobials, its amount decreased more in BC than in CIP cells. The downregulation of this chaperon protein is surprising considering its role in bacterial adaptation. In a study exposing Escherichia coli cells to a shock concentration of trimethoprim, this chaperonin complex was 1.4 fold times over-expressed [43].

The major capsid protein and putative tail sheath proteins, that were also under-expressed in BC and CIP adapted cells (Figure 2 and Table 1), have unknown function(s) yet and are encoded by genes that are part of a previously described genomic island (GI), PAGI-6 [44]. This GI is an example of a prophage that has undergone multiple recombination and deletion events resulting in $P$. aeruginosa altered virulence [45]. The putative tail sheath protein has been also associated with membrane vesicles (MV). Membrane vesicles are naturally released from the bacterial outer surface and are constituted of OM proteins, lipopolysaccharides and periplasmic components. P. aeruginosa MV

\begin{tabular}{|c|c|c|c|c|c|c|c|c|c|c|c|c|}
\hline \multirow{2}{*}{$\begin{array}{l}\text { Protein } \\
\text { num- } \\
\text { ber }^{\mathrm{a}}\end{array}$} & \multirow[t]{2}{*}{ Protein } & \multirow{2}{*}{$\begin{array}{c}\text { Accession } \\
\text { number }\end{array}$} & \multirow{2}{*}{$\begin{array}{l}\text { Subcellular } \\
\text { Localiza- } \\
\text { tion }^{\text {b }}\end{array}$} & \multirow{2}{*}{$\begin{array}{c}M \\
(k D a)\end{array}$} & \multirow[t]{2}{*}{ pl } & \multirow{2}{*}{$\begin{array}{l}\mathrm{N}^{\mathrm{er}} \text { of } \\
\text { matching } \\
\text { peptides }\end{array}$} & \multirow{2}{*}{$\begin{array}{l}\text { Mas- } \\
\text { cot } \\
\text { Score }\end{array}$} & \multirow{2}{*}{$\begin{array}{l}\text { ANOVA } \\
\text { (p) }\end{array}$} & \multicolumn{4}{|c|}{ Normalized volumes mean (S.D.)c } \\
\hline & & & & & & & & & TSB & BC & CIP & \\
\hline 3241 & $\begin{array}{c}\text { Chain A, Crystal Structure of the } \\
\text { Asymmetric Chaperonin Complex } \\
\text { GroelGROES (ADP)7 }\end{array}$ & 38491472 & $\mathrm{C}$ & 57.3 & 4.85 & 10 & 363 & $3,303 e-4$ & $5.79(0.047)$ & $5.05(0.25)$ & $-5.32(0.16)$ & - \\
\hline 3407 & GroEL & 6225121 & C & 56.6 & 4.85 & 6 & 293 & $3,845 e-4$ & $6.16(0.063)$ & $5.62(0.063)$ & $-6.00(0.21)$ & - \\
\hline 4114 & GroEL & 6225123 & $\mathrm{C}$ & 56.6 & 4.85 & 3 & 162 & $1,214 \mathrm{e}-4$ & $6.40(0.032)$ & $5.51(0.21)$ & $-6.08(0.22)$ & - \\
\hline 4186 & Putative tail sheath protein & 148807411 & OM & 41.9 & 5.00 & 3 & 156 & $1,873 e-4$ & $6.98(0.099)$ & $6.61(0.18)$ & $-6.39(0.066)$ & - \\
\hline 4306 & Putative tail sheath protein & 148807411 & OM & 57.3 & 5.00 & 1 & 47 & $1,190 \mathrm{e}-4$ & $6.52(0.18)$ & $5.75(0.14)$ & - $6.47(0.19)$ & - \\
\hline 7063 & Hypothetical protein PA0537 & 15595734 & $U$ & 22.1 & 8.63 & 9 & 462 & $2,038 \mathrm{e}-6$ & $6.66(0.06)$ & $5.68(0.057)$ & - $6.35(0.16)$ & - \\
\hline 10599 & Predicted major capsid protein & 148807393 & 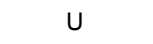 & 37.8 & 5.83 & 7 & 371 & $2,930 \mathrm{e}-4$ & $6.6(0.012)$ & $5.4(0.56)$ & - $5.25(0.21)$ & - \\
\hline 10603 & Predicted major capsid protein & 148807393 & $U$ & 37.8 & 5.83 & 10 & 455 & $4,328 \mathrm{e}-4$ & $6.93(0.20)$ & $5.84(0.13)$ & - $5.81(0.49)$ & - \\
\hline 10615 & Bacteriophage protein & 15595819 & $\mathrm{C}$ & 41.2 & 5.27 & 1 & 49 & $4,966 \mathrm{e}-4$ & $6.35(0.26)$ & $5.73(0.32)$ & - $\quad 6.69(0.12$ & + \\
\hline 10689 & $\begin{array}{l}\text { Type IV fimbrial biogenesis outer } \\
\text { membrane protein PilQ precursor }\end{array}$ & 254244078 & OM & 77.3 & 5.56 & 8 & 317 & $3,751 \mathrm{e}-4$ & $6.0(0.18)$ & $6.6(0.14)$ & $+5.59(0.35)$ & - \\
\hline
\end{tabular}

Protein numbers refer to those in Figur

${ }^{b}$ Localization prediction according to genome annotation, PSORTdb 2.0 and www.pseudomonas.com

${ }^{c}$ Symbols represent differential expression of proteins in adapted strains compared with reference strain: $(-)$ down regulated, $(+)$ up regulated 
are a component of the matrix of the $P$. aeruginosa mature biofilm and contain some virulence factors, including proteases, phospholipase C, alkaline phosphatase, and antibacterial factors [46]. However, the fact that $P$. aeruginosa biofilm cells underexpressed this protein after induced adaptive resistance might suggest membrane degradation (and perhaps the release of vesicles) in adapted cells. The hypothetical protein, PA0537, was also down-regulated in adapted sessile cells (Figure 2 and Table 1).

\section{Overexpressed proteins}

The type 4 fimbrial biogenesis outer membrane protein PilQ precursor was over-expressed in biofilms adapted to BC and underexpressed in CIP-adapted cells (Figure 2 and Table 1). PilQ is essential for $P$. aeruginosa pilus formation particularly for type IV pilus [47], and is consequently involved in the bacterial motility and the adhesion [47]. Nde et al. [47] reported the downregulation of the gene pilQ after $P$. aeruginosa exposure for $60 \mathrm{~min}$ to chlorhexidine diacetate (CHX). According to this author, the mechanism of action of $\mathrm{CHX}$ in $P$. aeruginosa involves changes in outer membrane permeability. BC and CHX having similar action at the membrane level, however, the discrepancy observed here might be due to the sessile growth mode in this work in opposition to the planktonic growth reported by Nde et al. [47]. The probable bacteriophage protein was overexpressed in biofilms adapted to CIP (Figure 2 and Table 1). As the putative tail sheath protein, this protein is a MV protein in $P$. aeruginosa. Several studies

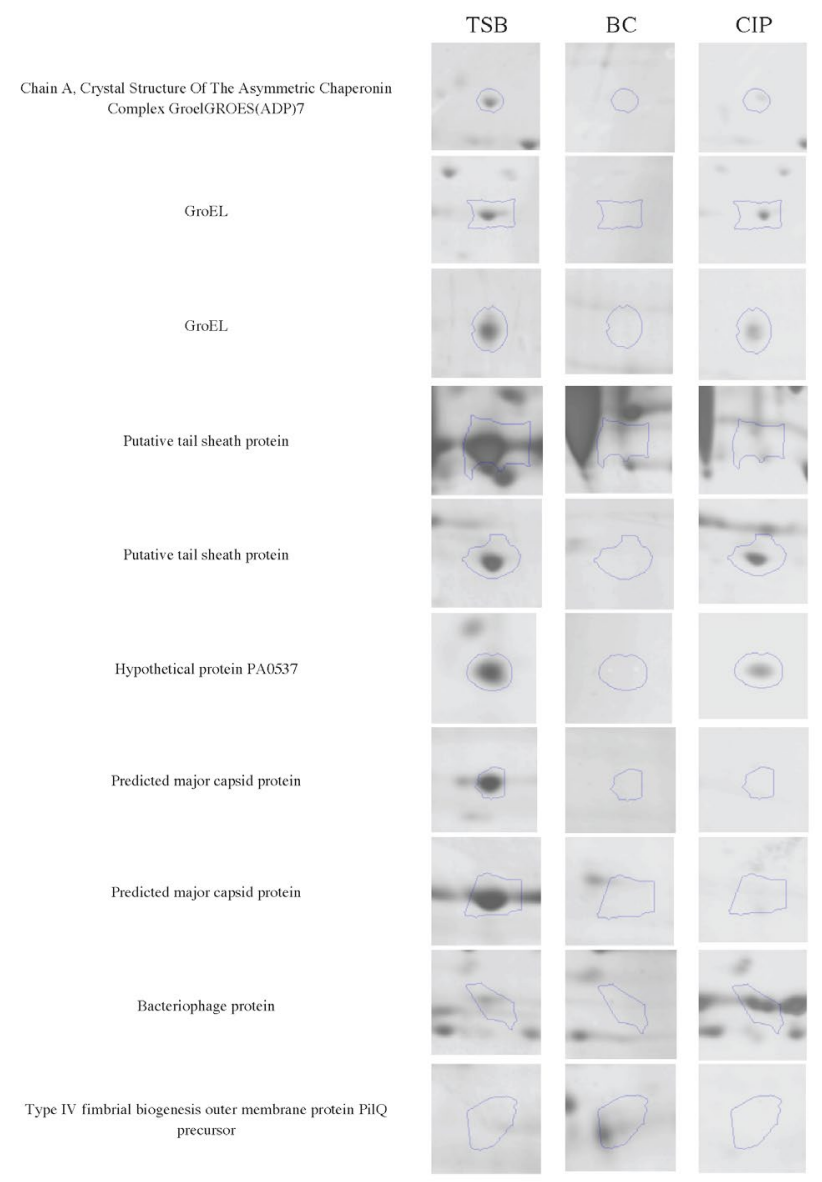

Figure 2: Comparison of the behaviour selected proteins in normal (TSB) and adapted to benzalkonium chloride (BC) and ciprofloxacin (CIP) biofilmentrapped cells of $P$. aeruginosa. have suggested that the most highly activated genes in sessile bacteria are those of temperate bacteriophages $[48,49]$. These take part in the diversification and phenotypic variation, including the production of small colony variants phenotypes [50]. Biofilms were developed under antimicrobial stress which may regulate proteins related with phages that may be involved in the population diversity found within biofilms [51], and can influence bacteria phenotype, in particular regarding adhesion potential, hydrophobicity and swimming and twitching motilities [52]. All these described features can increase the ability of a biofilm to survive under stress conditions [5].

\section{Conclusion}

A proteomic approach was here used to characterize the alterations of the outer membrane proteome of $P$. aeruginosa biofilm cells after $\mathrm{BC}$ and CIP adaptation. The regulation of OMPs is a cause of the adaptive process. This study demonstrated that proteins involved in pili and vesicles formation, and phage related proteins exhibited different amount in BC and CIP adapted sessile cells as compared with nonadapted counterparts. Also, the differential expression of some OM proteins after exposure to both antimicrobials was observed, revealing a possible link between the bacteria response within biofilms when exposed to different external pressures. Further proteome studies will provide more comprehensive information on protein variations and reveal biofilm resistance mechanisms, allowing the identification of candidate target proteins for novel antibiotics and defining some possible cross-resistance mechanisms associated with both antimicrobial products.

\section{Acknowledgement}

Funding sources: The financial support from IBB-CEB and Fundação para a Ciência e Tecnologia (FCT) and European Community fund FEDER, trough Program COMPETE, in the ambit of the Project PTDC/SAUESA/6460912006 /FCOMP-01-0124-FEDER-007480, Idalina Machado PhD Grant (SFRH/ $\mathrm{BD} / 31065 / 2006)$ is gratefully acknowledged.

\section{References}

1. Imperi F, Ciccosanti F, Perdomo AB, Tiburzi F, Mancone C, et al. (2009) Analysis of the periplasmic proteome of Pseudomonas aeruginosa, a metabolically versatile opportunistic pathogen. Proteomics 9: 1901-1915.

2. Lindsay D, von Holy $A$ (2006) Bacterial biofilms within the clinical setting: what healthcare professionals should know. J Hosp Infect 64: 313-325.

3. Davies DG, Chakrabarty AM, Geesey GG (1993) Exopolysaccharide production in biofilms: substratum activation of alginate gene expression by Pseudomonas aeruginosa. Appl Environ Microbiol 59: 1181-1186.

4. Ryder C, Byrd M, Wozniak DJ (2007) Role of polysaccharides in Pseudomonas aeruginosa biofilm development. Curr Opin Microbiol 10: 644-648.

5. Machado I, Lopes SP, Sousa AM, Pereira MO (2012) Adaptive response of single and binary Pseudomonas aeruginosa and Escherichia coli biofilms to benzalkonium chloride. J Basic Microbiol 52: 43-52.

6. Szomolay B, Klapper I, Dockery J, Stewart PS (2005) Adaptive responses to antimicrobial agents in biofilms. Environ Microbiol 7: 1186-1191.

7. Dworkin J, Shah IM (2010) Exit from dormancy in microbial organisms. Nat Rev Microbiol 8: 890-896.

8. Bjarnsholt T, Ciofu O, Molin S, Givskov M, HÃ iby N (2013) Applying insights from biofilm biology to drug development - can a new approach be developed? Nat Rev Drug Discov 12: 791-808.

9. Dötsch A, Becker T, Pommerenke C, Magnowska Z, JÃansch L, et al. (2009) Genomewide identification of genetic determinants of antimicrobial drug resistance in Pseudomonas aeruginosa. Antimicrob Agents Chemother 53 2522-2531.

10. Fernández L, Hancock RE (2012) Adaptive and mutational resistance: role of porins and efflux pumps in drug resistance. Clin Microbiol Rev 25: 661-681. 
Citation: Machado I, Coquet L, Pereira MO, Jouenne T (2016) Proteomic Changes in Pseudomonas aeruginosa Biofilm Cells after Adaptive Resistance Development. J Proteomics Bioinform 9: 058-062. doi:10.4172/jpb.1000390

11. Mangalappalli-Illathu AK, Korber DR (2006) Adaptive resistance and differential protein expression of Salmonella enterica serovar Enteritidis biofilms exposed to benzalkonium chloride. Antimicrob Agents Chemother 50: 3588-3596.

12. Fernández L1, Breidenstein $E B$, Hancock RE (2011) Creeping baselines and adaptive resistance to antibiotics. Drug Resist Updat 14: 1-21.

13. Voigt WG, Johnson CR (1976) Aestivation and thermoregulation in the Texas tortoise, Gopherus berlandieri. Comp Biochem Physiol A Comp Physiol 53: 41 44.

14. Machado I, Coquet L, Jouenne T, Pereira MO (2013) Proteomic approach to Pseudomonas aeruginosa adaptive resistance to benzalkonium chloride. J Proteomics 89: 273-279.

15. Steyn B, Oosthuizen MC, MacDonald R, Theron J, Brözel VS (2001) The use of glass wool as an attachment surface for studying phenotypic changes in Pseudomonas aeruginosa biofilms by two-dimensional gel electrophoresis. Proteomics 1: 871-879.

16. Collet A, Cosette P, Beloin C, Ghigo JM, Rihouey C, et al. (2008) Impact of rpoS deletion on the proteome of Escherichia coli grown planktonically and as biofilm. J Proteome Res 7: 4659-4669.

17. Nigaud Y, Cosette P, Collet A, Song PC, Vaudry D, et al. (2010) Biofilm-induced modifications in the proteome of Pseudomonas aeruginosa planktonic cells. Biochim Biophys Acta 1804: 957-966.

18. Jurtshuk P, McEntire JE (1975) Characterization studies on the membranebound adenosine triphosphatase (ATPase) of Azotobacter vinelandii. Can J Microbiol 21: 1807-1814

19. Crow TJ, Deakin JF, Longden A (1975) Proceedings: Do anti-psychotic drugs act by dopamine receptor blockade in the nucleus accumbens. $\mathrm{Br} \mathrm{J}$ Pharmaco 55: 295P-296P.

20. Schmoldt A, Benthe HF, Haberland G (1975) Digitoxin metabolism by rat liver microsomes. Biochem Pharmacol 24: 1639-1641.

21. Trémoulet $F$, Duché $O$, Namane A, Martinie B, Labadie JC (2002) A proteomic study of Escherichia coli O157:H7 NCTC 12900 cultivated in biofilm or in planktonic growth mode. FEMS Microbiol Lett 215: 7-14.

22. Trémoulet $F$, Duché $O$, Namane A, Martinie B, Labadie JC; European Listeria Genome Consortium (2002) Comparison of protein patterns of Listeria monocytogenes grown in biofilm or in planktonic mode by proteomic analysis. FEMS Microbiol Lett 210: 25-31.

23. Scherberger RR, Kaess $H$, Brückner S (1975) Studies on the action of an anticholinergic agent in combination with a tranquilizer on gastric juice secretion in man. Arzneimittelforschung 25: 1460-1463.

24. Hefford MA, D'Aoust S, Cyr TD, Austin JW, Sanders G, et al. (2005) Proteomic and microscopic analysis of biofilms formed by Listeria monocytogenes 568 . Can J Microbiol 51: 197-208.

25. Vilain S, Brözel VS (2006) Multivariate approach to comparing whole-cell proteomes of Bacillus cereus indicates a biofilm-specific proteome. J Proteome Res 5: 1924-1930.

26. Seneviratne CJ, Wang Y, Jin L, Wong SS, Herath TD, et al. (2012) Unraveling the resistance of microbial biofilms: has proteomics been helpful? Proteomics 12: 651-665.

27. Chow YW, Pietranico R, Mukerji A (1975) Studies of oxygen binding energy to hemoglobin molecule. Biochem Biophys Res Commun 66: 1424-1431.

28. Winder CL, Al-Adham IS, Abdel Malek SM, Buultjens TE, Horrocks AJ, et al. (2000) Outer membrane protein shifts in biocide-resistant Pseudomonas aeruginosa PAO1. J Appl Microbiol 89: 289-295.

29. Vilain S, Cosette $P$, Charlionet $R$, Hubert $M$, Lange $C$, et al. (2001) Substituting Coomassie Brilliant Blue for bromophenol blue in two-dimensional electrophoresis buffers improves the resolution of focusing patterns. Electrophoresis 22: 4368-4374.

30. Rabilloud T, Charmont S (2000) Detection of proteins on two-dimensiona electrophoresis gels, in Proteome Research: Two-dimensional Gel Electrophoresis and Identification Methods. Heidelberg: Springer-Verlag: Berlin.

31. Kleinhaus AL (1975) Electrophysiological actions of convulsants and anticonvulsants on neurons of the leech subesophageal ganglion. Comp Biochem Physiol C 52: 27-34.
32. Roskoski R Jr, Lim CT, Roskoski LM (1975) Human brain and placental choline acetyltransferase: purification and properties. Biochemistry 14: 5105-5110.

33. Braoudaki M, Hilton AC (2005) Mechanisms of resistance in Salmonella enterica adapted to erythromycin, benzalkonium chloride and triclosan. Int J Antimicrob Agents 25: 31-37.

34. Eickenroht EY, Gause EM, Rowlands JR (1975) The interaction of SO2 with proteins. Environ Lett 9: 265-277.

35. Leisman GB, Waukau J, Forst SA (1995) Characterization and environmenta regulation of outer membrane proteins in Xenorhabdus nematophilus. App Environ Microbiol 61: 200-204.

36. Leopold K, Jacobsen S, Nybroe O (1997) A phosphate-starvation-inducible outer-membrane protein of Pseudomonas fluorescens Ag1 as an immunological phosphate-starvation marker. Microbiology 143: 1019-1027.

37. Adewoye LO, Worobec EA (1999) Multiple environmental factors regulate the expression of the carbohydrate-selective OprB porin of Pseudomonas aeruginosa. Can J Microbiol 45: 1033-1042.

38. Stancik LM, Stancik DM, Schmidt B, Barnhart DM, Yoncheva YN, et al. (2002) $\mathrm{pH}$-dependent expression of periplasmic proteins and amino acid catabolism in Escherichia coli. J Bacteriol 184: 4246-4258

39. Paju S, Goulhen F, Asikainen S, Grenier D, Mayrand D, et al. (2000) Localization of heat shock proteins in clinical Actinobacillus actinomycetemcomitans strains and their effects on epithelial cell proliferation. Fems Microbiology Letters 182 231-235.

40. Khemiri A, Galland A, Vaudry D, Chan Tchi Song P, Vaudry H, et al. (2008) Outer-membrane proteomic maps and surface-exposed proteins of Legionella pneumophila using cellular fractionation and fluorescent labelling. Anal Bioanal Chem 390: 1861-1871.

41. Ellis RJ1 (2005) Chaperomics: in vivo GroEL function defined. Curr Biol 15 R661-663.

42. Hennequin $C$, Porcheray $F$, Waligora-Dupriet $A$, Collignon $A$, Barc $M$, et al (2001) GroEL (Hsp60) of Clostridium difficile is involved in cell adherence. Microbiology 147: 87-96.

43. Laskowska E, KuczyÅ ,ska-WiÅınik D, Bak M, LipiÅ,ska B (2003) Trimethoprim induces heat shock proteins and protein aggregation in $E$. coli cells. Curr Microbiol 47: 286-289.

44. Battle SE, Rello J, Hauser AR (2009) Genomic islands of Pseudomonas aeruginosa. FEMS Microbiol Lett 290: 70-78.

45. Kung VL, Ozer EA, Hauser AR (2010) The accessory genome of Pseudomonas aeruginosa. Microbiol Mol Biol Rev 74: 621-641.

46. Molloy MP, Herbert BR, Slade MB, Rabilloud T, Nouwens AS, et al. (2000) Proteomic analysis of the Escherichia coli outer membrane. Eur J Biochem 267: 2871-2881.

47. Nde CW, Jang HJ, Toghrol F, Bentley WE (2009) Global transcriptomic response of Pseudomonas aeruginosa to chlorhexidine diacetate. Environ Sci Technol 43: 8406-8415

48. Autrup H, Warwick GP (1975) Some characteristics of two azoreductase systems in rat liver. Relevance to the activity of 2-[4'-di(2"-bromopropyl)aminophenylazo]benzoic acid (CB10-252), a compound possessing latent cytotoxic activity. Chem Biol Interact 11: 329-342.

49. Whiteley M, Bangera MG, Bumgarner RE, Parsek MR, Teitzel GM, et al. (2001) Gene expression in Pseudomonas aeruginosa biofilms. Nature 413: 860-864.

50. Rehm BHA (2008) Pseudomonas Model Organism, Pathogen, Cell Factory. Weinheim: WILEY-VCH Verlag GmbH \& Co.

51. Megerman J, Murphy RA (1975) Myosin from arterial smooth muscle: isolation following actin depolymerization. Biochim Biophys Acta 412: 241-255.

52. Kirisits MJ, Prost L, Starkey M, Parsek MR (2005) Characterization of colony morphology variants isolated from Pseudomonas aeruginosa biofilms. App Environ Microbiol 71: 4809-4821.

Citation: Machado I, Coquet L, Pereira MO, Jouenne T (2016) Proteomic Changes in Pseudomonas aeruginosa Biofilm Cells after Adaptive Resistance Development. J Proteomics Bioinform 9: 058-062. doi:10.4172/jpb.1000390 